\title{
Control of Macromolecular Composition and Cell Division in the Blue-green Alga Anacystis nidulans
}

\author{
By N. MANN AND N. G. CARR \\ Department of Biochemistry, University of Liverpool, P.O. Box_i 147 , \\ Liverpool L69 $3 B X$
}

(Received 18 March 1974)

\begin{abstract}
SUMMARY
The cell volume and macromolecular composition, in terms of DNA, RNA and cell mass, were examined in Anacystis nidulans at different growth rates of the organism. Both DNA and RNA increased exponentially with increasing growth rate, as has been found in several heterotrophic bacteria. However, in this bluegreen alga the ratio of DNA to RNA was independent of growth rate. Cell mass and volume also increased exponentially with growth rate though at a slower rate than RNA and DNA. These results also indicate a constant ratio of tRNA and rRNA to DNA in contrast to the situation in heterotrophic bacteria so far studied.

The variation of cell volume in this organism can be related to the control of cell division, and indicates that the commencement of DNA replication and the processes of cell division are associated with the achievement of a critical cell volume, as has been demonstrated for Escherichia coli.
\end{abstract}

\section{INTRODUCTION}

The ways in which macromolecular composition and cell size vary in response to the growth rate have been examined in several heterotrophic bacteria (Schaechter, Maaløe \& Kjeldgaard, 1958; Neihardt \& Magasanik, 1960; Rosset, Julien \& Monier, 1966; Gray \& Midgley, 1970; Skjold, Juarez \& Hedgcoth, 1973) and much of the relevant data have been reviewed by Maaløe \& Kjeldgaard (1966). The pattern observed was that DNA, RNA, protein and cell mass all increased exponentially with growth rate. Cell mass increased at a rate slightly greater than DNA/cell, which increased at the same rate as protein/cell. The most significant observation was the greatly increased levels of RNA relative to DNA at fast growth rates. The relative levels of rRNA and tRNA have also been examined as a function of growth rate. The results indicated an increase in the relative level of rRNA with increasing growth rate (Kjeldgaard \& Kurland, 1963; Forchhammer, Kjeldgaard \& Moldave, 1965; Rosset et al. 1966; Forchhammer \& Lindahl, 1971; Gray \& Midgley, 1970; Skjold et al. 1973).

It has been demonstrated in Escherichia coli by Cooper \& Helmstetter (1968) that the time of initiation of rounds of DNA synthesis in the cell cycle varied in relation to the previous cell division, but that there was a constant interval of approximately 60 min between initiation of DNA replication and subsequent cell division. This period of $60 \mathrm{~min}$ comprised an initial 40 min during which DNA replication occurred and a further 20 min before the subsequent cell division. It follows that when the organism is growing at mean generation times shorter than $40 \mathrm{~min}$, it becomes necessary to begin a second round of DNA replication before the previous one is completed, leading to a greater DNA content in faster growing cells. 
The combination of these results with observations of Schaechter et al. (1958) that the average cell size was an exponential function of growth rate was shown by Donachie (1968) to indicate that the initiation of a round of DNA replication takes place when the ratio of cell mass to chromosome origins achieves a certain critical value. Thus the cell size at initiation will be an integral multiple of a particular cell mass, dependent on the number of chromosome origins. This accounts for the increasing size of cells with growth rate and indicates methods by which the cell can regulate initiation of DNA replication (Donachie, 1968).

We examined whether a dependence of macromolecular composition on growth rate exists in the obligately phototrophic micro-organism, Anacystis nidulans, and whether the nutritional mode of this organism is reflected in differences, in its control of macromolecular composition, from the pattern found in heterotrophic bacteria.

\section{METHODS}

Growth conditions. Anacystis niduians (Indiana University Culture Collection strain 625) was grown in medium $\mathrm{C}$ (Kratz iz Myers, 1955) supplemented with $0 \cdot 1 \% \mathrm{NaHCO}_{3}$ in $1 \mathrm{l}$ reaction vessels at $34{ }^{\circ} \mathrm{C}$. The cultures were gassed with $95 \%$ air $/ \mathrm{CO}_{2}$ at a rate of I $00 \mathrm{ml} / \mathrm{min}$ and illuminated by $75 \mathrm{~W}$ reflector lamps (Cryselco) $\mathrm{I} 2 \mathrm{~cm}$ from both sides of the culture. Under these conditions, mean generation times of approximately $3 \mathrm{~h}$ were achieved. Alterations of the incident light intensity were employed to produce differing mean generation times. Cell mass (as mneasured by $E_{650}$ ) and cell number were monitored to establish that the organism was in a steady state of growth. After at least 4 generations of balanced growth samples were withdrawn for estimation of cell volume, DNA/cell and RNA/cell. Under the conditions emp oyed, exponential growth of the organism would continue until an $E_{650}$ of approximately 0.8 was reached; experimental samples were always withdrawn while the $E_{650}$ was between 0.4 and 0.6 .

RNA estimation. Four samples each containing at least $10^{9}$ cells were cooled in ice and harvested. The pellet was washed twice with $10 \mathrm{ml}$ absolute alcohol and the organisms resuspended in $2.5 \mathrm{ml} 0.2 \mathrm{M}-\mathrm{NaCl}$ and $0.1 \mathrm{ml} 60 \%$ perchloric acid. After incubation at $70{ }^{\circ} \mathrm{C}$ for $80 \mathrm{~min}$ the suspension was chilled in ice and centrifuged. The ribose in the supernatant was then estimated by a modification (Taggart, ${ }^{9667)}$ of the orcinol reaction (Schneider, I 957), in which $\mathrm{I} \mathrm{ml}$ of the supernatan 1 was heated to $100{ }^{\circ} \mathrm{C}$ for $30 \mathrm{~min}$ with $1.0 \mathrm{ml} 0.05 \%$ $(\mathrm{w} / \mathrm{v}) \mathrm{FeCl}_{3}$ in concentrated $\mathrm{HCl}$ and $0.1 \mathrm{ml} 6.0 \%(\mathrm{w} / \mathrm{v})$ ethanolic orcinol. The samples were then chilled in ice and the colour stabilized by the addition of $20 \%(\mathrm{v} / \mathrm{v})$ ethanol. The $E_{650}$ of the samples was measured against a reagent blank and the results compared with D-ribose standards.

DNA estimation. Four samples each containing at least $4 \times 10^{9}$ cells were cooled in ice and perchloric acid added to a final concentration of $0.5 \mathrm{~N}$. After $20 \mathrm{~min}$ the organisms were centrifuged, resuspended in $0.5 \mathrm{~N}$-perchloric acid and incubated at $70{ }^{\circ} \mathrm{C}$ for $40 \mathrm{~min}$. The extracts were then chilled in ice, centrifuged, and $\mathrm{I} \mathrm{ml}$ samples of the supernatant assayed for DNA by the diphenylamine method of Burton (1956) and compared with D-deoxyribose standards.

Estimation of cell number. A suitable dilution of unstained organisms was placed in a Neubauer counting chamber and, after allowing $15 \mathrm{~min}$ for the cells to settle out, was counted. The electronic particle counter (see below) was also employed for this purpose.

Estimation of cell volume. Cell volurne was estimated by means of an electronic particle counter (Model ZB, Coulter Electrorics Ltd, Dunstable). A sample of the culture was 


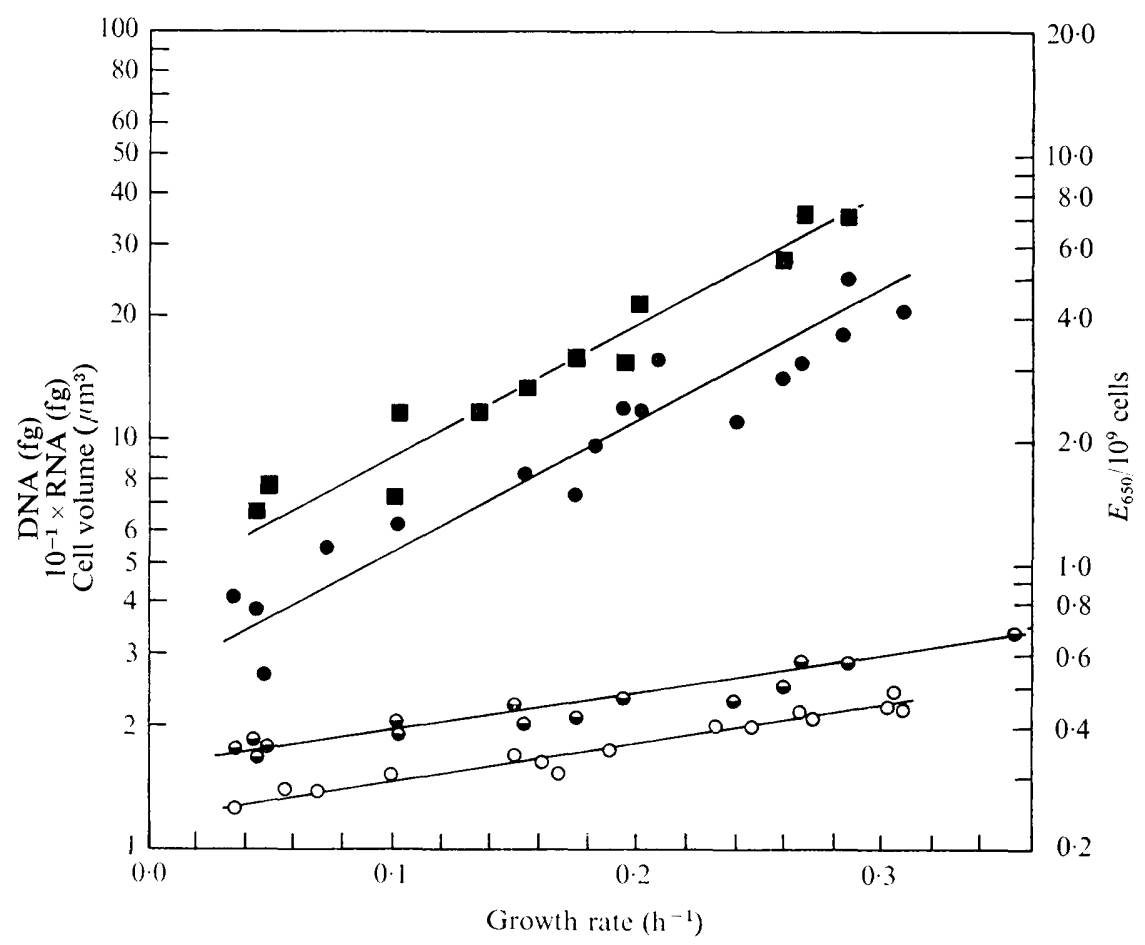

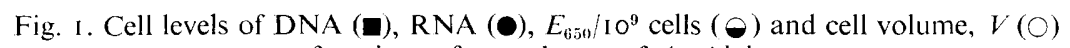
as functions of growth rate of $A$. nidulans.

suitably diluted in Isoton (Coulter Electronics Ltd) and by using dual threshold settings the distribution of cell volumes between 0.37 and $4.57 \mu \mathrm{m}^{3}$ was obtained. A mean cell volume was calculated from these results.

\section{RESULTS AND DISCUSSION}

Experimental growth was maintained under a variety of different light intensities and samples were analysed for DNA and RNA (see ordinate, Fig I), mean cell volume $V\left(\mu \mathrm{m}^{3}\right)$ and $E_{650} /$ cell. The relationships of these parameters to growth rate are shown in semilogarithmic plots (Fig. I) and are expressed below as a series of equations, where $\mu$ is the growth rate and the constant is derived from the intercept on the ordinate axis at zero growth rate.

$$
\begin{aligned}
\log \text { DNA } & =3.327 \mu+0.627, \\
\log \text { RNA } & =3.243 \mu+0.393, \\
\log V & =0.962 \mu+0.07 \mathrm{I}, \\
\log \left(E_{650} / 10^{9} \text { cells }\right) & =0.900 \mu+0.522 .
\end{aligned}
$$

The relationships which existed in Anacystis nidulans between DNA/cell, RNA/cell and cell size with growth rate were qualitatively similar to those found in heterotrophic bacteria (see Introduction), in that there is an exponential increase of these parameters with increasing growth rate. Two important quantitative differences exist, however, in that cell mass increased more slowly than DNA/cell with growth rate and that the DNA/RNA ratio was independent of growth rate. The constant DNA/RNA ratio has also been observed in the filamentous blue-green alga Anabaena variabilis (Leach, Old \& Carr, 1971). The significance of this observation is emphasized by the fact that the relative levels of tRNA and 


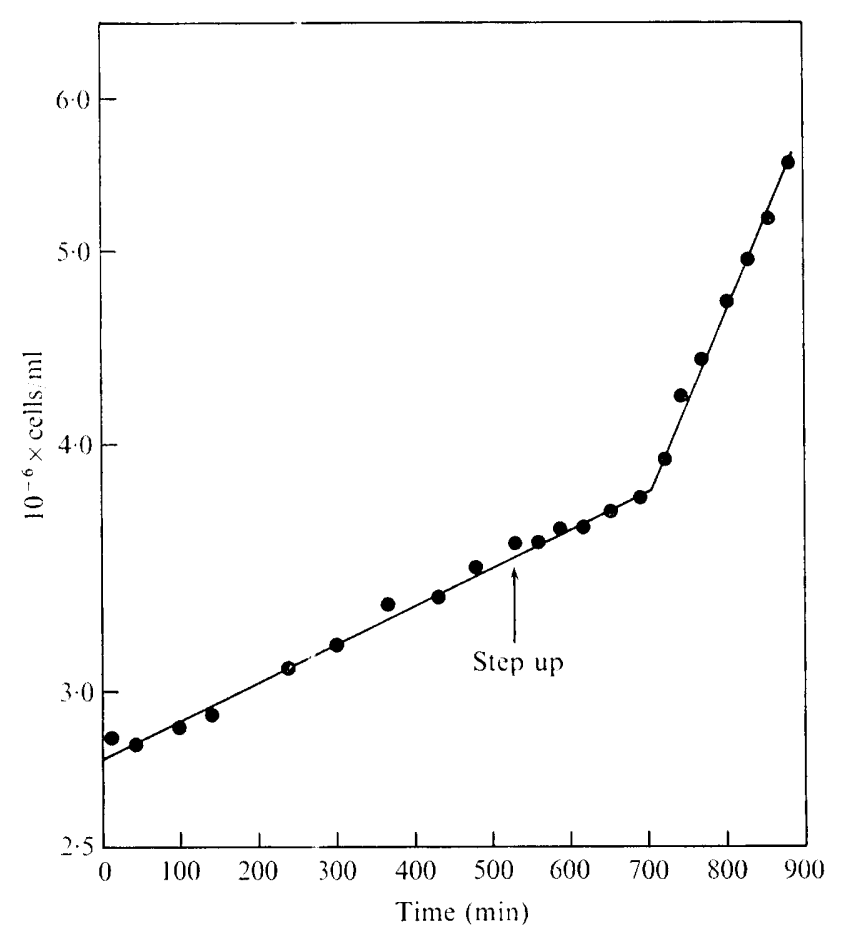

Fig. 2. The increase in cell number of $A$. nidulans during a 'step up' induced by increased light intensity.

rRNA do not vary with growth rate (Mann \& Carr, 1973) and the ratios of these two stable species to DNA are also independent of growth rate, whereas in several species of heterotrophic bacteria (see Introduction) a variation of the relative levels of tRNA and rRNA has been reported. It would seem thal $A$. nidulans is unable to respond to an altered growth rate by an alteration in the relative frequency of transcription of the stable RNA genes. This is in accord with the suggestion (Carr, I973) that the underlying feature of obligate phototrophy may be a lack of selective gene expression.

The response of bacterial cells taken from a nutritionally poor to a rich medium, a step up' transition, is to maintain the old rate of cell division for a characteristic length of time before the new rate of cell division is established (Kjeldgaard, 1961; Sud \& Schaechter, 1964; Schleif, 1967; Kjeldgaard, 1967). This maintenance of the rate of cell division at the rate prior to step-up may be explained in terms of the $C$ and $D$ intervals, where $C$ is the time taken for a replication fork to travese the chromosome and $D$ is the time between the completion of replication and subsequent division. After $(C+D) \min$ in the new medium the cells begin dividing at the new rate characteristic of the medium, as a consequence of the increased frequency of insertion of replication forks which can only be expressed in cell division after $(C+D)$ min (Helmstetter, Cooper, Pierucci \& Revelas, r968).

The time taken for a culture of $A$. niciulans to achieve a new rate of cell division, the step-up time, was measured after an increase in the incident light intensity (Fig. 2). Four such experiments gave an average step-up time for cell division of $178 \mathrm{~min}$.

It has been shown (Donachie, 1968) that the initiation of DNA replication is related to the achievement of a critical cell volume by the bacterial cell. By combining the estimate of $(C+D)$ from the step-up experiments with the rate of change of cell volume with growth 


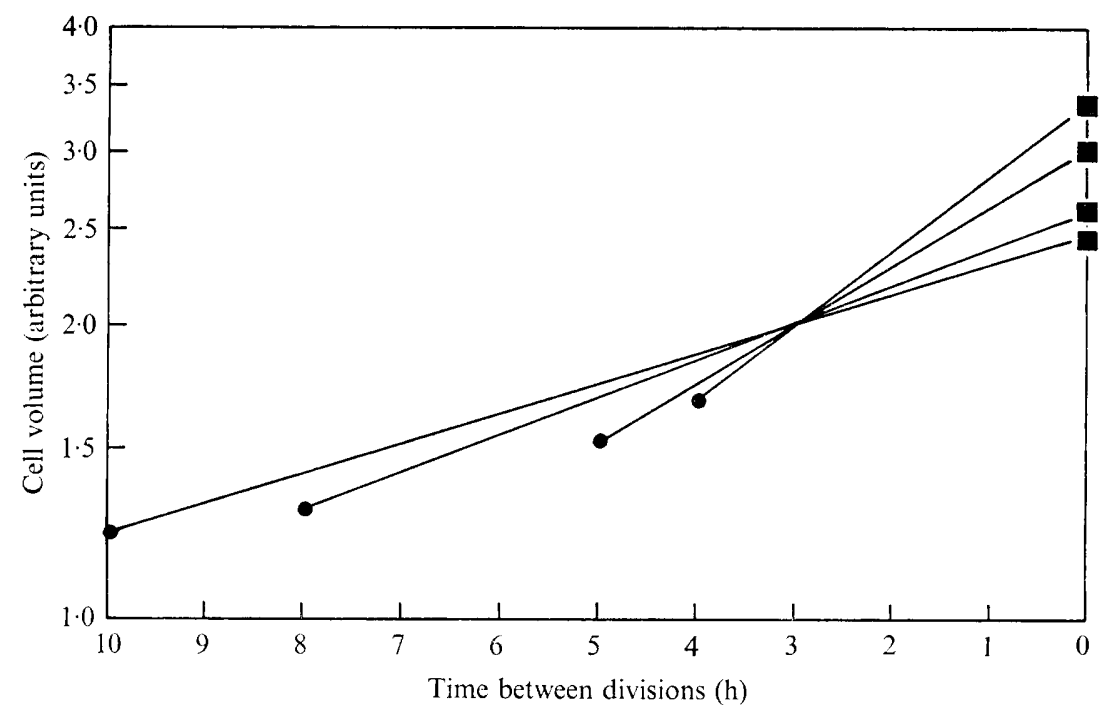

Fig. 3. The growth of individual cells at four different growth rates, from the volume just after division (O) to the volume just before division $(\boldsymbol{\square})$. For the arbitrary units of cell volume, cell volume just after division is taken as unit volume, at an infinitely long mean generation time.

rate it becomes possible to demonstrate a similar kind of relationship in A. nidulans. Assuming that the volume of the cell just after division bears a constant relationship to the average volume of the cell at that particular growth rate, the growth of individual cells between divisions may be represented (Fig. 3). Growth is expressed logarithmically, because it has been shown by Bazin (see Williams, I97I) that in $A$. nidulans the growth of the individual cell approximates most closely to an exponential model. It is clear that at about $178 \mathrm{~min}$ $(C+D)$ before division the cell achieves a certain critical volume, regard'ess of the rate at which the cell is growing and consequently regardless of the average volume of the cell population.

It has been shown (Donachie, 1968; Pritchard, Barth \& Collins, 1969) that the mean cell volume can be related to the growth rate by the equation:

$$
V=k \times 2^{(c++) / g}
$$

where $k$ is a constant and $g$ is the mean generation time (h).

If the $(C+D)$ value of $178 \mathrm{~min}$ is introduced into this equation it predicts that a plot of $\log V$ versus growth rate $(=1 / g)$ should have a slope of 0.90 , which is in good agreement with the observed value of $0.96 \mathrm{~h}^{-1}$ and the value $0.90 \mathrm{~h}^{-1}$ (see eqns 3 and 4 ) calculated from the slopes for cell volume and $E_{650} / 10^{9}$ cells in Fig. I. The interptetation of the cell cycle of Anacystis nidulans in terms of the $C$ and $D$ intervals is supported by the measurement of DNA replication time and the ensuing interval before cell division in synchronous cultures of A. nidulans (Herdman, Faulkner \& Carr, 1970) where $C$ and $D$ had values of 65 and I 5 min respectively.

It is apparent that the relationship of cell volume to growth rate in A. nidulans and the behaviour of cells during a step-up can be satisfactorily described in terms of the analysis of the cell cycle as used by Cooper \& Helmstetter (1968). However, efforts to describe DNA/cell or genome equivalents/cell in terms of $(C$ and $D)$ and the growth rate have failed. Before a culture of $A$. nidulans has reached a growth rate at which a second round of DNA replication begins before the cell divides, i.e. at mean generation times shorter than $C+D$, 
the DNA content of the cell is already of the order of 16 times greater than the DNA content at zero growth rate obtained by extrapolation of the DNA/cell slope in Fig. I. At present there is no satisfactory model to describe this increase in DNA content.

N.M. acknowledges receipt of a Medical Research Council training scholarship. We are grateful to Dr M. Herdman and Dr C. K. Leach for valuable criticism.

\section{REFERENCES}

BURTON, K. (1956). A study of the conditions and mechanism of the diphenylamine reaction for the colorimetric estimation of deoxyribonucleic acid. Biochemical Journal 62, 315-323.

CARR, N. G. (1973). Metabolic control and autotrophic physiology. In The Biology of the Blue-Green Algae, pp. 39-65. Edited by N. G. Carr and B. A. Whitton. Oxford: Blackwell Scientific Publications.

COOPER, S. \& HelmstetTer, C. E. (1968). Chromosome replication and the division cycle of Escherichia coli I 5. Journal of Molecular Biology 31, 5 ( 9-540.

Donachie, W. D. (1968). Relationship between cell size and time of initiation of DNA replication. Nature, London 219, 1077-1079.

Forchhammer, J., KJeldgaArd, N. O. \& Moldave, K. (1965). The relative amount and in vivo decay of messenger RNA under growth shifts in E. coli 'TAU-bar'. Proceedings of the National Academy of Science of the United States of America 48, I-4.

ForChHAmmer, J. \& Lindahl, L. (1971). Growth rate of polypeptide chains as a function of the cell growth rate in a mutant of Escherichia coli I 5. Journal of Molecular Biology 55, 563-568.

Gray, W. \& Midgley, J. (1970). The control of ribonucleic acid synthesis in bacteria. Biochemical Journal I20, 279-288.

Herdman, M., Faulkner, B. \& Carr, N. G. (1970). Synchronous growth and genome replication in the blue-green alga Anacystis nidulans. Archiv fiir Mikrobiologie 73, 238-249.

Helmstetter, C., Cooper, S., Pierucci, O. \& Revelas, E. (1968). On the bacterial life sequence. Cold Spring Harbor Symposia on Quantitative Biology 33, 809-822.

KJELDGAard, N. O. (1961). The kinetics of RNA and protein formation in Salmonella typhimurium during the transition between different states of balanced growth. Biochimica et biophysica acta 49, 64-76.

KJELDGAARD, N. O. (1967). Regulation of nucleic acid and protein formation in bacteria. In Advances in Microbial Physiology, vol. I, pp. 39-95. Edited by A. H. Rose and J. F. Wilkinson. London and New York: Academic Press.

KJeldgaARD, N. O. \& KurLand, C. G. (1963). The distribution of soluble and ribosomal RNA as a function of growth rate. Journal of Molecular Biology 6, 34I-348.

Kratz, W. A. \& Myers, J. (1955). Nutrit on and growth of several blue-green algae. American Journal of Botany 42, 282-287.

LEACH, C. K., OLD, J. M. \& CARR, N. G. (1 971). Aspects of macromolecular synthesis in the blue-green alga Anabaena variabilis. Journal of General Microbiology 68, xiv.

MaAløe, O. \& KJeldgaArd, N. O. (1966). Control of Macromolecular Synthesis. New York: W. A. Benjamin.

MANN, N. \& CARR, N. G. (1973). A consıant ratio of transfer to ribosomal ribonucleic acid in Anacystis nidulans grown with differing mean generation times. Biochemical Society Transactions I, 702-704.

Neihardt, F. C. \& MagasaniK, B. (1960). Studies on the role of ribonucleic acid in the growth of bacteria. Biochimica et biophysica acta 42, 99-II 6.

Pritchard, R. H., Barth, P. T. \& Collins, J. (1969). Control of DNA synthesis in bacteria. Symposia of the Society for General Microbiology 19, 263-297.

Rosset, R., JULIEN, J. \& MONIER, R. (I966). Ribonucleic acid composition of bacteria as a function of growth rate. Journal of Molecular Biology 18, 308-320.

Schaechter, M., Maaløe, O. \& KJeldgatrd, N. O. (1958). Dependence on medium and temperature of cell size and chemical composition during balanced growth in Salmonella typhimurium. Journal of General Microbiology 19, 592-606.

SCHLEIF, R. (1967). Control of production of ribosomal protein. Journal of Molecular Biology 27, 4I-55.

SCHNeIder, W. C. (1957). Determination of nucleic acids in tissues by pentose analysis. In Methods in Enzymology, vol. 3, pp. 680-684. Edited by S. P. Colowick and N. O. Kaplan. New York: Academic Press. 
Sk.Jold, A. C., JuAREz, H. \& Hedgcoth, C. (1973). Relationships among deoxyribonucleic acid, ribonucleic acid and specific transfer ribonucleic acids in Escherichia coli ${ }_{1} \mathrm{~T}^{-}$at various growth rates. Journal of Bacteriology II5, $177-187$.

Sud, I. J. \& Schaechter, M. (1964). Dependence of the content of cell envelopes on the growth rate of Bacillus megaterium. Journal of Bacteriology 88, 1612-1617.

I AGGART, J. (1967). Heptulose phosphate synthesis and the transaldolase reaction in plant tissues. Ph.D. thesis, University of Liverpool.

Williams, F. M. (1971). Dynamics of microbial populations. Systems Analysis and Simulation in Ecology I, $197-267$. 